\title{
ANALISIS KEMAMPUAN PEMECAHAN MASALAH MATEMATIS BERDASARKAN TEORI POLYA DITINJAU DARI GAYA KOGNITIF FIELD DEPENDENT DAN FIELD INDEPENDENT PADA POKOK BAHASAN TRIGONOMETRI KELAS X SMA N 1 KOTA JAMBI
}

\author{
Elsa Manora Siahaan ${ }^{1}$, Sri Dewi ${ }^{2}$, Hasan Basri Said ${ }^{3}$ \\ Program Studi Pendidikan Matematika, FKIP, Universitas Batanghari ${ }^{1,2,3}$ \\ Jl. Slamet Riyadi No.1 Broni Jambi \\ Email : -
}

\begin{abstract}
ABSTRAK
Penelitian bertujuan mengetahui kemampuan pemecahan masalah matematis ditinjau dari gaya kognitif field dependent dan field independent pada siswa kelas X SMA Negeri 1 Kota Jambi Tahun Ajaran 2017-2018 yang berjumlah 198 siswa. Subjek yang diambil dalam penelitian ini sebanyak 6 orang, yaitu 3 siswa dengan gaya kognitif field dependent dan 3 siswa siswa dengan gaya kognitif field independent. Metode pengumpulan data yang digunakan dalam penelitian ini adalah metode angket tes gaya kognitif, tes kemampuan pemecahan masalah matematis dan pedoman wawancara. Data yang diperlukan diperoleh melalui tes pemecahan masalah matematis, dan pedoman wawancara yang telah diuji terlebih dahulu melalui uji pendapat validator, data tes angket gaya kognitif telah baku tanpa diuji cobakan oleh pendapat validator. Teknik analisis data yaitu meliputi (1) reduksi data, (2) pemaparan data, dan (3) penarikan kesimpulan serta digunakan triangulasi waktu. Hasil penelitian ini menunjukkan perbedaan kemampuan pemecahan masalah matematis antara keenam subjek pada langkah menyelesaikan masalah dan mengecek kembali, yaitu subjek FI dalam menyelesaikan masalah sesuai rencana dan mengecek kembali hasil yang diperoleh lebih baik dibandingkan subjek FD dalam menyelesaikan masalah dan mengecek kembali hasil.Hal ini terlihat dari jawaban subjek dan indicator pemecahan masalah matematis, kemudian terlihat dari jawaban tes wawancara berdasarkan tahapan Polya.
\end{abstract}

Kata Kunci:

Kemampuan Pemecahan Masalah Matematis, Gaya Kognitif Field Dependent dan Field Independent.

\begin{abstract}
The study aims to determine the ability of mathematical problem solving in terms of the field dependent and independent field cognitive styles in class X students of SMA Negeri 1 Jambi City Academic Year 2017-2018, totaling 198 students. Subjects taken in this study were 6 people, namely 3 students with a field dependent cognitive style and 3 students with an independent field cognitive style. Data collection methods used in this study were cognitive style questionnaire tests, mathematical problem-solving abilities tests and interview guidelines. The data needed is obtained through mathematical problem solving tests, and interview guidelines that have been tested first through the validator opinion test, the cognitive style questionnaire test data has been standardized without being tested by the validator's opinion. Data analysis techniques include (1) data reduction, (2) data exposure, and (3) conclusion drawing and time triangulation. The results of this study indicate differences in mathematical problem solving abilities between the six subjects in the steps of solving problems and rechecking, namely the FI subject in solving problems according to plan and rechecking the results obtained are better than the FD subject in solving problems and re-checking results. from the answers of the subjects and indicators of mathematical problem solving, then seen from the answers to the interview test based on Polya's stages.
\end{abstract}


Keywords:

Mathematical Problem Solving Ability, Field Dependent and Independent Field Cognitive Style.

\section{PENDAHULUAN}

Matematika merupakan salah satu mata pelajaran yang sangat penting bagi para siswa. Kenyataan itu salah satunya diperkuat oleh pendapat Marquis de Condorcet (Shadiq, 2014) yang menyatakan : "Mathematics... , is the best training for our abilities, as it develops both the power and the precision of our thinking." Artinya: "Matematika adalah cara terbaik untuk melatih kemampuan berpikir kita, karena matematika dapat mengembangkan kekuatan berpikir dan ketepatan berpikir kita".

Menurut Depdiknas (Shadiq, 2014) ada lima tujuan pembelajaran matematika yang harus dicapai para siswa dari selama proses pembelajaran di kelas matematika, yaitu;

1. Memahami konsep matematika, menjelaskan keterkaitan antar konsep dan mengaplikasikan konsep atau algoritma, secara luwes, akurat, efisien dan tepat dalam pemecahan masalah.

2. Menggunakan penalaran pada pola dan sifat, melakukan manipulasi matematika dalam membuat generalisasi, menyusun bukti, atau menjelaskan gagasan dan pernyataan matematika.

3. Memecahkan masalah yang meliputi kemampuan memahami masalah, merancang model matematika, menyelesaikan model dan menafsirkan solusi yang diperoleh.

4. Mengomunikasikan gagasan dengan simbol, tabel, diagram, atau media lain untuk memperjelas keadaan atau masalah.

5. Memiliki sikap menghargai kegunaan matematika dalam kehidupan, yaitu rasa ingin tahu, perhatian, dan minat dalam mempelajari matematika, serta sikap ulet dan percaya diri dalam pemecahan masalah.

Pemecahan masalah merupakan salah satu metode yang tepat untuk mempelajari dan mengerjakan matematika. Siswa yang memiliki keterampilan dalam memecahkan masalah, akan memiliki beberapa keuntungan, diantaranya mengembangkan kemampuan berpikir kritis, memperkuat keterampilan matematika.

Menurut Polya (Herry, 2015) ada empat tahap pemecahan masalah yaitu: (1) memahami masalah, (2) membuat rencana penyelesaian, (3) melaksanakan rencana, dan (4) melihat kembali. Hal ini berarti penyelesaian permasalahan belum dianggap sebagai hasil final sebelum diperiksa kembali kesesuaiannya terhadap informasi yang disediakan. Dengan menggunakan langkah-langkah pemecahan masalah oleh Polya, diharapkan siswa dapat dengan lebih runtut dan terstruktur dalam memecahkan masalah matematika.

Berdasarkan hasil observasi lapangan yang dilakukan peneliti pada tanggal 27 Februari 2018 sampai dengan 9 Maret 2018 di SMA Negeri 1 Kota Jambi bahwa proses belajar mengajar pada materi trigonometri masih tergolong membosankan dimana setelah guru selesai menjelaskan, siswa disuruh mengerjakan soal latihan. Sehingga siswa kebanyakan bosan dan masih banyak yang belum mengerti dalam mengikuti pelajaran.

Pada saat memecahkan masalah, setiap individu memiliki karakteristik 


\section{$\pi$ (Phi)}

khas yang tidak dimiliki oleh individu lain. Oleh karena itu, dapat dikatakan bahwa setiap individu berbeda dengan yang lainnya. Salah satu tinjauan perbedaan ini adalah dari aspek-aspek perseptual dan intelektual. Aspek perseptual dan intelektual mengungkapkan bahwa setiap individu mempunyai ciri khas yang berbeda dengan individu lain. Sesuai dengan tinjauan aspek perseptual dan intelektual tersebut, dikemukakan bahwa perbedaan individu dapat diungkapkan oleh tipe-tipe kognitif yang dikenal dengan gaya kognitif (cognitive style) (Herry, 2015).

Gaya kognitif merupakan potensi apabila dimanfaatkan dalam upaya peningkatan keefektifan proses belajar mengajar. Siswa akan mencapai hasil yang optimal apabila belajar sesuai dengan gaya belajar siswa. Salah satu jenis gaya kognitif membagi manusia atas dua bagian, yakni Field Dependent (FD) dan Field Independent (FI). Meskipun terdapat dua jenis gaya kognitif yang berbeda, tetapi tidak dapat dikatakan bahwa siswa yang field independent lebih baik dari siswa yang field dependent atau sebaliknya. Masing-masing siswa field dependent atau field independent mempunyai kelebihan dalam bidangnya. Berdasarkan perbedaan gaya inilah menjadi menarik untuk dapat diungkap pemahaman siswa terhadap konsep materi pelajaran tentang trigonometri dari masing-masing kelompok gaya kognitif. Witkin (Susanto, 2015) menyatakan bahwa individu yang bersifat analitik adalah individu yang memisahkan lingkungan ke dalam komponen-komponennya, kurang bergantung pada lingkungan atau kurang dipengaruhi oleh lingkungan. Individu ini dikatakan termasuk gaya kognitif Field Independent (FI). Adapun individu yang bersifat global adalah individu yang memfokuskan pada lingkungan secara keseluruhan, didominasi atau dipengaruhi lingkungan. Individu tersebut dikatakan termasuk gaya kognitif Field Dependent (FD).

Jadi dalam menyelesaikan masalah matematika siswa, seorang guru harus memperhatikan gaya kognitif siswa dalam melaksanakan pembelajaran. Perlunya guru memperhtikan gaya kognitif siswa dalam proses pembelajaran diharapkan dapat membantu siswa untuk mencapai tujuan pembelajaran secara maksimal.

Langkah pemecahan masalah yang peneliti gunakan disini adalah teory Polya karena dalam teory Polya langkah-langkah pemecahan masalahnya lebih runtut dan terstruktur yang memudahkan siswa untuk memecahkan masalah.

Berdasarkan uraian permasalahan yang telah dipaparkan, perlu adanya penelitian lebih lanjut mengenai "Analisis Kemampuan Pemecahan Masalah Matematis Berdasarkan Teori Polya Ditinjau Dari Gaya Kognitif Field Dependent Dan Field Independent Pada Pokok Bahasan Trigonometri Kelas X SMA Negeri 1 Kota Jambi”.

Menurut Bell (Roebyanto dan Harmini, 2017) suatu situasi dikatakan masalah bagi seseorang jika ia menyadari keberadaan situasi tersebut, mengakui bahwa situasi tersebut memerlukan tindakan dan tidak dengan segera dapat menemukan pemecahannya.

Pada umumnya suatu masalah adalah situasi yang memenuhi beberapa peeryaratan sebagai berikut (Roebyanto dan Harmini, 2017) :

1. Situasi tersebut menunjukkan adanya kesenjangan antara harapan dan kenyataan.

2. Situasi tersebut membangkitkan motivasi bagi orang tersebut untuk 


\section{$\pi$ (Phi)}

berupaya menemukan jalan keluarnya.

3. Tidak tersedia secara instan alat yang dapat digunakan untuk mewujudkan keinginan orang tersebut untuk menemukan jalan keluarnya.

Ciri-ciri suatu soal disebut masalah paling tidak memuat dua hal yaitu (Ayu Yarmayani, 2018) :

1. Soal tersebut menantang pikiran.

2. Soal tersebut tidak otomatis diketahui cara penyelesaiannya.

Menurut Solso dkk (2008)

Pemecahan masalah adalah suatu pemikiran yang terarah secara langsung untuk menemukan suatu solusi/ jalan keluar untuk suatu masalah yang spesifik. Kita menemukan banyak masalah dalam kehidupan sehari-hari kita, sehingga kita akan membuat suatu cara untuk menanggapi, memilih, menguji respons yang kita dapat untuk memecahkan suatu masalah.

Polya (Susanto, 2015) menyatakan bahwa: ..." to have a problem means: to search consciously for some action appropriate to attain a clearly conceived, but not immediately, aim. To solve a problem means to find such action. Artinya: Mempunyai masalah berarti mencari dengan sadar suatu tindakan yang tepat untuk mencapai suatu tujuan yang jelas, tetapi tindakan tersebut dengan segera dapat dicapai. Memecahkan masalah berarti mencari tindakan.

Pemecahan masalah dipandang sebagai suatu proses untuk menemukan kombinasi dari sejumlah aturan yang dapat diterapkan dalam upaya mengatasi situai yang baru. Pemecahan masalah tidak sekedar sebagai bentuk kemampuan menerapkan aturan-aturan yang telah dikuasai melalui kegiatankegiatan belajar terdahulu, melainkan lebih dari itu merupakan proses untuk mendapatkan seperangkat aturan pada tingkat yang lebih tinggi. Pemecahan masalah memerlukan keterampilan berpikir yang banyak ragamnya termasuk mengamati, melaporkan, mendeskripsi, menganalisis, mengklasifikasi, menafsirkan, mengkritik, meramalkan, menarik kesimpulan dan membuat generalisasi berdasarkan informasi yang dikumpulkandandiolah (Fitriani, 2017)

Menurut Polya (Roebyanto dan Harmini, 2017) ada empat langkahlangkah pemecahan masalah yaitu sebagai berikut :

1. Pemahaman masalah (understanding the problem)

Hal ini meliputi:

a. Apakah yang tidak diketahui? Data apakah yang diberikan? Bagaimana kondisi soal?

b. Mungkinkah kondisi dinyatakan dalam bentuk persamaan atau hubungan lainnya?

c. Apakah kondisi yang diberkan cukup atau tidak untuk mencari apa yang ditanyakan?

2. Perencanaan penyelesaian (devising a plan)

Langkah ini menyangkut beberapa aspek penting sebagai berikut:

a. Pernahkah anda menemui soal seperti ini sebelumnya? Pernahkah ada soal yang serupa dalam bentuk lain?

b. Teori yang mana dapat digunakan dalam masalah ini?

c. Perhatikan apa yang ditanyakan atau coba pikirkan soal yang pernah diketahui dengan pertanyaan yang sama atau yang serupa.

3. Melaksanakan Perencanaan (carrying out the plan)

Langkah ini menekankan pada pelaksaan rencana penyelesaian. Prosedur yang ditempuh adalah:

a. Memeriksa setiap langkah apakah sudah benar atau belum? 


\section{$\pi$ (Phi)}

b. Bagaimana membuktikan bahwa langkah yang dipilih sudah benar?

4. Pemeriksaan kembali (looking back) Prosedur yang harus diperhatikan pada langkah ini yaitu:

a. Dapatkah diperiksa sanggahannya?

b. Dapatkah jawaban tersebut dicari dengan cara lain?

c. Dapatkah cara atau jawaban tersebut digunakan untuk soalsoal lain?

Berdasarkan langkah Polya tersebut dalam kemampuan pemecahan masalah matematis ada beberapa indikator pemecahan masalah menurut Budiman (Hendriana, 2017), yaitu sebagai berikut: (1) Mengidentifikasi kecukupan data untuk memecahkan masalah; (2) Membuat model matematika dari suatu masalah dan menyelesaikannya; (3) Memilih dan menerapkan strategi untuk menyelesaikan masalah matematika; (4) Memeriksa kebenaran hasil atau jawaban.

Dari beberapa uraian diatas maka indikator kemampuan pemecahan masalah matematis dalam penelitian ini adalah (1) Mengidentifikasi kecukupan data untuk memecahkan masalah; (2) Membuat model matematika dari suatu masala dan menyelesaikannya; (3) Memilih dan menerapkan strategi untuk menyelesaikan masalah matematika; (4) Memeriksa kebenaran hasil atau jawaban.

Setiap individu memiliki karakteristik khas, yang tidak dimiliki oleh individu lain. Oleh karena itu dapat dikatakan bahwa setiap individu berbeda satu dengan yang lain. Perbedaan karakteristik dari setiap individu dalam menanggapi informasi, merupakangaya kognitif individu yang bersangkutan. Gaya kognitif merujuk pada cara seseorang memproses, menyimpan maupun menggunakan informasi untuk menanggapi suatu tugas atau menanggapi berbagai jenis situasi lingkungannya. Disebut sebagai gaya dan bukan sebagai kemampuan karena merujuk pada bagaimana seseorang memproses informasi dan memecahkan masalah dan bukan merujuk pada bagaimana proses penyelesaian yang terbaik.

$\begin{array}{lrr}\text { Menurut } & \text { Broverman } & \text { (Susanto, } \\ \text { 2015) gaya } & \text { kognitif } & \text { adalah } \\ \text { menggambarkan cara } & \text { seseorang } \\ \text { memahami lingkungannya. } & \text { Menurut }\end{array}$
Kagan (Susanto, 2015) gaya kognitif yaitu sebagai variasi cara individu dalam menerima, mengingat dan memikirkan informasi atau perbedaan cara memahami, menyimpan, mentransformasi dan memanfaatkan informasi. Menurut Woolfolk (Susanto, 2015) gaya kognitif adalah bagaimana seseorang menerima dan mengorganisasikan informasi dari dunia sekitanya.

Menurut Nasution (2005) gaya kognitif memiliki tiga tipe yaitu: (1) field dependent-field independent ; (2) impulsive-reflektif ; (3) preseptifleseptif -sistematis/intuitif. Sedangkan menurut Woolfolk (Raudhatul, 2015:20) banyak variasi gaya kognitif yang diminati para pendidik, dan mereka membedakan gaya kognitif berdasarkan dimensi: (a) perbedaan aspek psikologis, yang terdiri dari field dependent (FD)dan field independent (FI), (b) waktu pemahaman konsep, yang terdiri dari gaya impulsive dan gaya reflective.

Dari beberapa pengertian diatas, mengungkapkan bahwa gaya kognitif adalah cara yang khas pemfungsian kegiatan perseptual (kebiasaan memberikan perhatian, menerima, menangkap, merasakan, menyeleksi, mengorganisasi, mengubah bentuk informasi intelektual) atau karakteristik individu dalam menerima, menyimpan 


\section{$\pi$ (Phi)}

maupun menggunakan informasi untuk menganggapi suatu tugas atau menanggapi berbagai jenis situasi lingkungannya.

Menurut Witkin ( Akramunnisa dkk, 2017)bahwa siswa yang memiliki gaya kognitif tipe field dependent cenderung mempersepsi suatu pola sebagai keseluruhan dan sukar baginya untuk memusatkan perhatian pada suatu aspek situasi atau menganalisis suatu pola menjadi bermaca-macam, sedangkan siswa yang memiliki gaya kognitif tipe field independent cenderung mempersepsi bagian-bagian yang terpisah dari suatu pola menurut komponen-komponenya.

Menurut Witkin dan Goodnough (Ngilawajan, 2013) individu dengan gaya kognitif field dependent adalah individu yang kurang atau tidak bisa memisahkan sesuatu bagian dari suatu kesatuan dan cenderung segera menerima bagian atau konteks yang dominan, sedangkan individu dengan gaya kognitif field independent adalah individu yang denga mudah dapat bebas dari persepsi yang terorganisir dan

Tabel 1. Karakteristik Gaya Kognitif Field Dependent dan Field Independent dari kesatuannya. yang dihadapinya. (Nasution, 2005) :

segera dapat memisahkan suatu bagian

Individu yang memiliki gaya kognitif field dependent mengalami kesulitan dalam membedakan stimulus melalui situasi yang dimiliki sehingga persepsinya mudah dipengaruhi oleh manipulasi dari situasi sekelilingnya. Individu yang sulit melepaskan diri dari keadaan yang mengacaukannya yaitu individu yang field dependent, akan menemukan kesulitan dalam masalahmasalah yang menuntut keterangan diluar konteks. Individu yangfield independent akanmengorganisir apa yang diteimanya sebagaimana yang disajikan. Sedang apa individu yang field independent akan mampu menanggulangi apa yang diterimanya dengan mencari komponen-komponen yang diletakkan pada permasalahan

Untuk lebih jelasnya dalam membandingkan kedua gaya kognitif tersebut disajikan dalam tabel 2 berikut

\section{Tipe : Field Dependent}

Sangat dipengaruhi oleh lingkungan banyak

bergantung pada pendidikan sewaktu kecil.

Dididik untuk selalu memperhatikan orang lain.

Mengingat hal-hal dalam konteks social, misalnya gadis : mengenakan rok meneurut panjang yang lazim.

Bicara lambat agar dapat dipahami orang lain.

Mempunyai hubungan social yang luas cocok untuk bekerja dalam bidang guidance, counseling, pendidikan dan social.

Lebih cocok untuk memilih psikologi klinis.

Lebih banyak terdapat dikalangan wanita.

Lebih sukar memastikan bidang mayornya dan sering pindah jurusan.

Tidak senang pelajaran matematika, lebih menyukai bidang humanitas dan ilmu-ilmu social.

Guru yang field dependent cenderung diskusi,

\section{Tipe : Field Independent}

Kurang dipengaruhi oleh lingkungan dan oleh pendidikan dimasa lampau.

Dididik untuk berdiri sendiri dan mempunyai otonomi atas tindakannya.

Tidak peduli akan norma-norma orang lain.

Berbicara cepat tanpa menghiraukan daya tangkap orang lain.

Kurang mementingkan hubungan social, sesuai untuk jabatan dalam bidang matematika, science, insinyur.

Lebih sesuai memilih psikologi eksperimental.

Banyak pria, namun yang overlapping.

Lebih cepat memilih bidang mayornya.

Dapat juga menghargai hubungan humanitas dan lmu-ilmu social, walaupun lebih cenderung kepada matematika dan ilmu pengetahuan alam.

Guru yang field independent cenderung 


\begin{tabular}{ll}
\hline \multicolumn{1}{c}{ Tipe : Field Dependent } & \multicolumn{1}{c}{ Tipe : Field Independent } \\
\hline demokratis. & $\begin{array}{l}\text { untuk membrikan kuliah, menyampaikan } \\
\text { pelajaran dengan memberitahukannya. }\end{array}$ \\
$\begin{array}{l}\text { Memerlukan petunjuk yang lebih banyak untuk } \\
\text { memahami sesuatu, bahan hendaknya tersusun langkah }\end{array}$ & Tidak memerlukan petunjuk yang terperinci. \\
$\begin{array}{l}\text { demi langkah. } \\
\begin{array}{l}\text { Lebih peka akan kritik dan perlu mendapat dorongan, } \\
\text { kritik jangan bersifat pribadi. }\end{array}\end{array}$ & Dapat menerima kritik demi perbaikan. \\
\hline
\end{tabular}

Berdasarkan tabel diatas dapat diketahui perbedaan ciri-ciri dari masing-masing individu field dependent maupun field independent. Meskipun terdapat dua kelompok gaya kognitif yang berbeda tetapi tidak dapat dikatakan bahwa siswa field independent lebih baik dari pada siswa field dependent. Setiap gaya kognitif mengandung kelebihan dan kekurangan.

Penggolongan siswa kedalam masing-msing gaya kognitif dilakukan dengan memberikan suatu test perseptual. Group Embedded Figures Test (GEFT) merupakan test perseptual yang menggunakan gambar. Seseorang yang menjalani test ini dihadapkan pada sekumpulan gambar-gambar rumit dan sederhana. Setiap gambar rumit terdapat salah satu gambar-gambar sederhana yang ditetapkan termuat pada masingmasing gambar sederhana.Tugas yang harus dikerjakan adalah mempertebal gambar sederhana yang ditetapkan termuat pada masing-masing gambar sederhana.

Dalam Group Embedded Figures Test (GEFT) terdapat tiga bagian, yaitu bagian pertama terdiri dari 7 gambar, bagian kedua 9 gambar dan bagian ketiga 9 gambar. Agar siswa lebih memahami cara menjawab GEFT, sebelum siswa memulai pada bagian pertama diberikan contoh sebanyak 1 soal. Pada GEFT bagian pertama terdiri dari 7 soal dimaksudkan untuk latihan, jadi perolehan skor tidak diperhitungkan dalam menganalisis penetapan gaya kognitif. Waktu yang disediakan untuk menyelesaikan GEFT bagian pertama selama 2 menit.Sedangkan GEFT bagian kedua dan ketiga merupakan tes yang sesungguhnya.Untuk menyelesaikan GEFT bagian kedua dan ketiga masingmasing disediakan waktu selama 5 menit.

\section{METODE PENELITIAN}

Jenis penelitian ini adalah penelitian kualitatif. Strategi penelitian yang digunakan adalah matode deskriptif. Penelitian ini bertujuan untuk menggambarkan tentang kemamampuan pemecahan masalah matematis siswa berdasarkan teori polya ditinjau dari gaya kognitif field dependent dan field independent pada pokok bahasan trigonometri kelas X SMA N 1 Kota Jambi.

Subjek dalam penelitian ini adalah siswa yang bergaya kognitif field dependent dan field independent yanf berjumlah enam orang.Instrumen yang digunakan dalam penelitian ini yaitu: peneliti sendiri dan instrument pendukung berupa tes GEFT, tes kemampuan pemecahan masalah, dan pedoman wawancara.

Teknik pengumpulan data yang dilakukan dalam penelitian ini adalah sebagai observasi, pemberian tse GEFT, tes kemampuan pemecahan masalag dan pedoman wawancara.Teknik analisis data yang dilakukan yaitu: reduksi data, penyajian data, dan penarikan kesimpulan. 


\section{$\pi$ (Phi)}

\section{HASIL DAN PEMBAHASAN}

Berdasarkan judul penelitian yang dilakukan yaitu "Analisis Kemampuan Pemecahan Masalah Matematis Berdasarkan Teori Polya Ditinjau Dari Gaya Kognitif Field Dependent dan Field Independent Pada Pokok Bahasan Trigonometri Kelas X MIPA SMA Negeri 1 Kota Jambi" maka data yang digunakan adalah siswa yang bergaya kognitif field dependent dan field independent. Kemudian dari siswa bergaya kognitif field dependent dipilih 3 orang siswa dengan skor tinggi yaitu Dandi (subjek 1 ), skor sedang yaitu Riska (subjek 2) dan skor rendah yaitu Brigita (subjek 3). Begitu pula dengan siswa yang bergaya kognitif field independent dipilih 3 orang siswa dengan skor tinggi yaitu Farid (subjek 4), skor sedang yaitu Intan (subjek 5) dan skor rendah yaitu Andreas (subjek $6)$.

Kemudian pada hari Senin tanggal 7 Mei 2018 pukul 07.45 pada saat jam pelajaran ke enam siswa tersebut dipanggil menuju ruangan kosong untuk diberikan soal tes kemampuan pemecahan masalah. Selanjutnya pada jam istirahat pukul 09.15 dilakukan wawancara kepada beberapa siswa. Soal yang diwawancarai adalah soal nomor 1 dan soal nomor 3 yang tela dikerjakan subjek.

Berikut ini sebagai petunjuk pemberian kode yang digunakan dalam mendeskripsikan hasil penelitian berbentuk penjabaran langkah-langkah teori Polya dan juga secara lebih jelas pada Bab 3 dalam teknik analisis data, yaitu :

S1FD : Subjek 1 dengan gaya kognitif field dependenttinggi.

S2FD : Subjek 2 dengan gaya kognitif field dependentsedang.

S3FD : Subjek 3 dengan gaya kognotif field dependentrendah.
S4FI : Subjek 4 dengan gaya kognotif field independenttinggi.

S5FI : Subjek 5 dengan gaya kognotif field independentsedang.

S6FI : Subjek 6 dengan gaya kognotif field independentrendah.

P01-S1FD-01 : Pertanyaan pertama pada subjek 1 untuk soal nomor satu.

P02-S1FD-01 : Pertanyaan kedua pada subjek 1 untuk soal nomor satu,dst

J01-S1FD-01 : Jawaban pertama subjek 1 untuk soal nomor satu.

J01-S1FD-02 : Jawaban pertama subjek 1 untuk soal nomor satu dua, dst.

Berdasarkan hasil pemecehan masalah matematis field dependent dan field independent yang telah dikemukakan, dapat diketahui bahwa pada langkah memahami masalah dan membuat rencana penyelesaian masalah tidak ada perbedaan keduanya. Dimana subjek field dependent dan field independent menerima informasi dengan cara yang sama yaitu membaca soal lebih dari sekali untuk memahami informasi yang terdapat pada soal. Setelah membaca soal tes pemecahan masalah tersebut, subjek field dependent dan field independent mengolah informasi tersebut dengan mengemukakan yang diketahui dan ditanyakan pada soal dengan menggunakan kalimatnya sendiri.

Perbedaan proses pemecahan masalah terjadi pada langkah melaksanakan rencana penyelesaian masalah matematis dan mengecek kembali. Pada langkah melaksanakan rencana penyelesaian masalah sesuai rencana subjek field dependent dan field independent sama-sama menggunakan konsep, atau operasi matematika yang telah mereka pahami sebelumnya. Namun pada langkah ini terdapat perbedaan penyelesaian masalah subjek 


\section{$\pi$ (Phi)}

field dependent. Ini menunjukkan bahwa kedua subjek memiliki memori kerja yang berbeda-beda, karena sesuai latar belakang pengetahuan yang dimilikinya. Hal ini sesuai dengan pendapat Wolfok (Kafiar Elisabeth dkk, 2015:46) yang mengatakan bahwa memori kerja bersifat individual. Ini berarti bahwa memori kerja yang dimiliki setiap subjek berbeda satu sama lain, ketika menghadapi masalah.

Perbedaan tersebut dipengaruhi oleh latar belakang pengetahuan yang dimilikinya. Subjek FI, sebelum merencanakan penyelesaian masalah terlebih dahulu menganalisis masalah tersebut. Hal ini sesuai dengan pendapat Witkin (Kafiar Elisabeth dkk, 2015:46) yang menyatakan bahwa individu FI cenderung berpikir analitis. Subjek FI menunjukkan kekonsistenan. Kekonsistenan subjek FI terlihat dari penggunaan konsep Aturan Sinus dan Cosinus dengan baik, sedangkan subjek FD menggunakan konsep dengan rumus yang salah seperti yang telah direncanakannya.

Dalam melaksanakan rencana penyelesaian masalah, pada masalah 1 dan masalah 2, subjek FI (S4FI, S5FI, S6FI) menunjukkan kekonsistenan dalam penggunaan konsep aturan sinus dan cosinus dengan baik, subjek FI bisa memecahkan masalah dalam soal tersebut. Sedangkan subjek FD (S1FD) pada masalah 1 dia menggunakan rumus yang benar tetapi jawaban akhirnya tidak tepat sedangkan pada masalah 2 subjek menggunakan rumus yang salah sehingga jawaban yang didapat pun tidak tepat, subjek FD (S2FD) pada masalah 1 dan masalah 2 menggunakan rumus yang salah sehingga masalah dalam soal pun tidak terselesaikan sedangkan subjek FD (S3FD) subjek hanya bisa membuat gambar dari yang diketahui sedangkan rumus untuk menyelesaikan masalah subjek tidak bisa mengingatnya.

Pada langkah memeriksa kembali hasil yang diperoleh subjek FI dan subjek FD sama-sama melakukan pemeriksaan pada hasil pengerjaannya. Subjek FI ketika memeriksa kembali hasil pengerjaannya subjek mendapat jawaban yang sama pada saat pengerjaan diawal sedangkan subjek FD ketika memeriksa kembali hasil pengerjaannya subjek mendapat jawaban yang sama padahal jawaban yang didapatnya itu sebenarnya kurang tepat.

Hasil penelitian ini didukung oleh Tomas (Kafiar dkk, 2015) yang menyatakan bahwa impilkasi gaya kognitif berdasarkan perbedaan psikologis pada siswa dalam pembelajaran, yaitu siswa yang memilih belajar individual, merespon dengan baik, dan independent. Menurut Ardana (Kafiar dkk, 2015), siswa yang memiliki gaya FI mempunyai tingkat kemandirian yang tinggi dalam mencermati suatu rangsangan tanpa ketergantungan dari faktor-faktor luar atau ketergantungan dari guru. Berdasarkan hasil penelitian yang diperoleh kemampuan pemecahan masalah matematika siswa yang memiliki gaya kognitif FI berbeda dengan siswa yang memiliki gaya kognitif FD dalam memecahkan masalah matematika. Dimana berdasarkan analisis data dapat disimpulkan bahwa subjek dengan gaya kognitif FI mempunyai tipe proses berpikir konseptual. Menurut Zuhri (Kafiar dkk, 2015) proses berpikir konseptual, yaitu proes berpikir yang selalu menyelesaikan soal dengan menggunakan konsep yang telah dimiliki bedasarkan hasil pelajarannya selama ini, dimana berdasarkan hasil tes tertulis dan wawancara diperoleh peneliti, subjek dengan gaya kognitif FI 


\section{$\pi$ (Phi)}

mampu mengungkapkan dengan kalimat sendiri apa yang diketahui dan ditanyakan dari soal, dan subjek juga mampu menyelesaikan masalah sesuai dengan rencana penyelesaian masalah, serta mampu menyelesaikan langkahlangkah penyelesaian maslaah dan dapat dapat mengecek kembali hasil yang diperoleh.

Pada subjek FD, dimana hasl penelitian ini didukung oleh Pujilestari (Kafiar dkk, 2015) yang mengatakan bahwa implikasi gaya kognitif berdasarkan perbedaan psikologis pada siswa dalam pembelajaran, yaitu siswa yang bergaya kognitif FD lebih mengalami kesulitan dalam menyelesaikan soal matematika, siswa pada kelompok FD masih belum dapat menggunakan informasi untuk merencanakan penyelesaian sehingga mengalami kesulitan dalam menentukan langkah-langkah dan perhitungan selanjutnya. Menurut Ardana (Kafiar dkk, 2015), siswa yang memiliki gaya kognitif FD biasanya lebih sulit membuat penyelesaian dari suatu masalah dengan mandiri. Hal ini karena siswa yang memiliki gaya kognitif FD sangat tergantung pada orang lain. Sedangkan menurut Crow et al (Kafiar dkk, 2015) mendefinisikan FD sebagai gaya kognitif seseorang yang cenderung dan sangat bergantung pada sumber informasi dari guru.

\section{SIMPULAN DAN SARAN}

Berdasarkan hasil penelitian dapat disimpulkan bahwa :

1. Kemampuan pemecahan masalah subjek FI dan subjek FD pada langkah memahami masalah dan membuat rencana penyelsaian masalah tidak ada perbedaan diantara keduanya. Dimana subjek FI dan subjek FD menerima informasi dengan membaca soal berulang-ulang hingga dirasa subjek dapat memahami soal, setelah membaca soal subjek FI dan subjek FD mengolah informasi tersebut dengan mengemukakan yang diketahui dan ditanyakan pada soal dengan menggunakan kalimat sendiri. Pada langkah membuat membuat rencana penyelesaian subjek FI dan subjek FD mengolah informasi ditunjukkan dengan membuat rencana penyelesaian, pada tahap menyimpan informasi dan memanggil kembali, ditunjukkan dengan cara mengingat pengetahuan terdahulu, yang dikaitkan dengan informasi yang baru diterima, sehingga subjek FI dan FD dapat membuat rencana penyelesaian dari soal.

2. Kemampuan pemecahan masalah subjek FI dan subjek FD pada langkah melaksanak rencana penyelesaian masalah sesuai rencana, subjek FI dan subjek FD sama-sama menggunakan konsep atau operasi mattematika yang telah dipahami sebelumnya. Namun pada langkah ini terdapat perbedaan penyelesaian subjek FI dan subjek FD. Pada langkah menyelesaikan masalah sesuai rencana subjek FI berhasil dengan baik dalam menyelesaikan masalah trigonometri dalam aturan sinus dan aturan cosinus. Sedangkan subjek FD pada langkah penyelesaian masalah sesuain rencana subjek FD kurang mampu menyelesaikan soal dengan baik sehingga hasil yang diperoleh tidak memuaskan.

3. Kemampuan pemecahan masalah subjek FI dan subjek FD pada langkah memeriksa kembali hasil yang diperoleh, subjek FI dan subjek FD sama-sama melaksanakan pemeriksaan ulang terhadap hasil yang telah diperoleh dan subjek FI dan subjek FD 


\section{$\pi$ (Phi)}

mendapat hasil yang sama pada proses pemecahan masalah yang subjek dapat tetapi sebenarnya jawaban yang diperoleh oleh subjek FD masih kurang tepat.

\section{DAFTAR PUSTAKA}

Akramunnisa.Dkk. 2017. Ability Analysis Based On Math Problem Completing The Early Math Skills And Cognitive Style Class VIII SMPN 13 Makassar. Jurnal Daya Matematis. Vol 5. No 1. 2017.

Arifin, Zainal. 2016. Evaluasi Pembelajaran. Bandung : PT Remaja Rosdakarya Offset.

Arikunto, S. 2002. Prosedur Penelitian: Suatu Pendekatan Praktek. Jakarta : PT Rineka Cipta.

Darmadi, H. 2013. Dimensi-dimensi Metode Penelitian Pendidikan Dan Sosial: Konsep Dasar Dan Implementasi. Bandung : Alfabeta.

Fitriani,

S. (2017).IdentifikasiPengetahuanM etakognisiSiswaKelas XI MIA SMAN 2 Kota Jambi Berdasarkan Gaya BelajarDalamPemecahanMasalah Matematika:JurnalIlmiahPendidik anMatematikaUniversitas

Batanghari Jambi.1(1).

Hendriana, H.dkk. 2017.Hard Skills dan Soft Skills Matematika Siswa. Bandung : PT Refika Aditama.

Kafiar, Elisabeth. Dkk. 2015. Proses Berpikir Siswa SMA Dalam Memecahkan Masalah Matematika Pada Materi SPLTV Ditinjau Dari Gaya Kognitif Field Independent Dan Field Dependent:

JurnalIlmiahMatematika Dan Pembelajarannya. 1 (2).

Lestari,K.A dan Yudhanegara, M.R. 2017. Penelitian Pendidikan
Matematika. Bandung : PT Refika Aditama.

Moleong, L.J. 2012. Metodologi Penelitian Kualitatif. Bandung : PT Remaja Rosdakarya.

Nasution, S. 2005. Berbagi Pendekatan Dalam Proses Belajar Mengajar dan Mengajar. Jakarta : PT Bumi Aksara.

Ngilawajan, Darma. Andreas. 2013. Proses Berpikir Siswa Dalam Memecahkan Masalah Matematika Materi Turunan Ditinjau Dari Gaya Kognitif Field Independent Dan Field Dependent :JurnalPendidikanMatematikaPE DAGOGIA. 2 (1).71-83.

Raudhatul, Fithri. 2015. Anallisis proses Penyelesaian Soal Cerita Berdasarkan Tahapan Polya Pokok Bahasan Kubus Dan Balok Pada Siswa Dengan Gaya Kognitif Field Dependent Kelas VIII-A SMP N 17 Kota Jambi. Skripsi. Jurusan Pendidikan Matematika dan IPA, FKIP UNJA Roebyanto, G danHarmini. S. 2017. Pemecahan Masalah Matematika Untuk PGSD. Bandung : PT Remaja Rosdakarya.

Shadiq, Fadjar. 2014. Strategi Pemodelan Pada Pemecahan Masalah Matematika. Yogyakarta : Graha Ilmu.

Solso, R. dkk. 2008. Psikologi Kognitif. PT Gelora Aksara Prata.

Sudijono, Anas. 2013. Pengantar Evaluasi Pendidikan. Jakarta : PT Raja Grafindo Persada.

Sugiono. 2017. Metode Penelitian Pendidikan: Pendekatan Kuantitatif, Kualitatif, dan $R \& D$. Bandung : Alfabeta.

Susanto, Herry. Agus. 2015. Pemahaman Pemecahan Masalah Berdasar Gaya Kognitif. Yogyakarta : Deepublish. 